\title{
Atropisomeric determination of chiral hydroxylated metabolites of polychlorinated biphenyls using HPLC-MS
}

\author{
Guangshu Zhai ${ }^{1}$ Xianai Wu ${ }^{2}$, Hans-Joachim Lehmler ${ }^{2}$ and Jerald $L$ Schnoor ${ }^{1,2^{*}}$
}

\begin{abstract}
Background: Polychlorinated biphenyls (PCBs) are a group of environmental persistent organic pollutants, which can be metabolized into a series of metabolites, including hydroxylated metabolites (OH-PCBs) in biota. Nineteen of 209 PCB congeners can form chiral stable isomers. However, atropisomeric determination of the hydroxylated metabolites of these chiral PCBs has never been reported by LC methods. In this work, a novel HPLC-MS method was developed to detect five chiral OH-PCBs (4OH-PCB91, 5OH-PCB91, 4OH-PCB95, 5OH-PCB95 and 5OH-PCB149) using HPLC-MS without a derivatization step.

Results: The influences of column-type, column temperature, flow rate and ratio of the mobile phase on the atropisomeric separation were investigated in detail. In the final method, calibration curves, based on peak areas against concentration, were linear in a range of $1-100 \mathrm{ng} \mathrm{mL}^{-1}$ of five chiral OH-PCBs with correlation coefficients ranging from 0.9996 to 0.9999 for all atropisomers of OH-PCBs. The relative standard deviations measured at the $10.0 \mathrm{ng} \mathrm{mL}^{-1}$ level for atropisomers of five chiral OH-PCBs were in the range of $0.60-7.55 \%(n=5)$. Calculated detection limits $(\mathrm{S} / \mathrm{N}=3)$ of five chiral $\mathrm{OH}-\mathrm{PCBs}$ were between 0.31 and $0.60 \mathrm{ng} \mathrm{mL}^{-1}$ for all $\mathrm{OH}-\mathrm{PCB}$ atropisomers.

Conclusion: This HPLC-MS method was developed to detect chiral OH-PCBs and further successfully applied to measure $\mathrm{OH}-\mathrm{PCB}$ atropisomer levels and enantiomeric fractions (EFs) in rat liver microsomal samples. The results from LC-MS method were highly consistent with those from GC-ECD method. It is the first time to report these $\mathrm{OH}-\mathrm{PCB}$ atropisomers detected in microsomes by HPLC-MS. The proposed method might be applied also to detect chiral OH-PCBs in environmental samples and for metabolites of PCBs in vivo.
\end{abstract}

Keywords: Chiral polychlorinated biphenyls, Hydroxylated metabolites, HPLC-MS, Rat liver microsome

\section{Background}

The persistence and wide application of polychlorinated biphenyls (PCBs) in past decades have led to their ubiquitous occurrence in the environment [1]. PCBs can adversely affect human health via bioaccumulation and biomagnification in the food chain [2]. Among 209 congeners, nineteen of PCBs with 4-8 chlorines are chiral and they can form stable rotational isomers, or atropisomers, that are nonsuperimposable mirror images of each other [3]. Furthermore, at least 12 chiral PCBs, including PCBs 91, 95 and 149, are present in commercial

\footnotetext{
* Correspondence: jerald-schnoor@uiowa.edu

'Department of Civil and Environmental Engineering and IIHR Hydroscience and Engineering, The University of lowa, lowa City 52242, IA, USA

${ }^{2}$ Department of Occupational and Environmental Health, The University of
} lowa, lowa City 52242, IA, USA

PCB mixtures [4]. Therefore, several chiral PCBs were detected in environmental media, such as soil $[5,6]$, sediment [7], aquatic and riparian biota (fish, bivalves, crayfish, water snakes, barn swallows) [8], birds [9], shark and grouper [10], dolphins [11], whale [12], human feces and liver $[13,14]$.

Chiral PCBs, like other chiral compounds, have special functions on elucidating the environmental and toxicological processes via their specific changes in enantiomeric fraction (EF) (enantioselectivity) during their metabolism and degradation because only the biological factors can affect the EF changes. The latest comprehensive review on chiral PCBs transport, metabolism and distribution covered the latest findings of chiral PCBs, including chiral PCB metabolites (such as methylsulfonyl-PCBs and hydroxy-PCBs), in the environmental and toxicological 
fields [15]. It was seen that the introduction of a hydroxy, methoxy or methylsulfonyl group will add an additional element of asymmetry so that hydroxy, methoxy or methylsulfonyl-PCBs are still chiral compounds [16]. Among the metabolites of chiral PCBs, hydroxy-PCBs (OH-PCBs) are frequently reported. It is well-known that the atropisomers of chiral PCBs showed different toxicity [15]. However, the field on toxicity of chiral metabolites of PCBs is still in its infancy. Therefore, it is necessary to develop sensitive and selective detection methods for chiral metabolites of PCBs, including chiral OH-PCBs.

Gas chromatographic methods with different detectors, such as mass spectrometry (GC-MS) [17-20] and electron capture detector (GC-ECD) [21-25], are presently the most common methods for the determination of $\mathrm{OH}-\mathrm{PCBs}$ in environmental matrices. However, the interaction of the hydroxyl groups in OH-PCBs with basic sites in the injector and column leads to difficulties in direct analyses of $\mathrm{OH}-\mathrm{PCBs}$ by gas chromatography. Abraham et al. [26] tried to directly detect the OH-PCBs but failed due to tailing chromatographic peaks and irreproducible peak areas. Derivatization of the OH-PCBs can eliminate the influence of the hydroxyl group on the separation and increase the volatility and stability, making them more amenable to gas chromatographic analysis. Thus, OH-PCBs can be derivatized using different derivatization reagents, such as diazomethane, diazoethane, acetyl, trifluoroacetyl, or pentafluoropropionyl analogues before gas chromatographic analysis [26-28]. However, the derivatization procedure is a timeconsuming step and one of the main sources of error due to incomplete derivatization $[27,29]$. The separation of chiral $\mathrm{OH}-\mathrm{PCBs}$ poses additional challenges because one chiral PCB congener may be metabolized into several chiral $\mathrm{OH}-\mathrm{PCBs}$, such as $\mathrm{PCB} 95$ producing $4 \mathrm{OH}-\mathrm{PCB} 95$, $5 \mathrm{OH}-\mathrm{PCB} 95$, and each chiral OH-PCB has two atropisomers. Up to now, chiral OH-PCBs, including OH-PCB 91, 95, 132, 136 and 149, have been successfully detected only by gas chromatographic methods [30-32].

High performance liquid chromatography-mass spectrometry (HPLC-MS) has the great advantage to determine chiral $\mathrm{OH}-\mathrm{PCB}$ because no derivatization step is needed, which avoids the loss of analyte during the derivatization step and saves a lot of time. However, there are more challenges to separate the atropisomers of chiral OH-PCBs for HPLC method than GC method because the resolution of HPLC shorter chiral columns is relatively lower than that of longer GC column. Therefore, few papers have reported the analysis of chiral PCB hydroxyl metabolites by HPLC-MS. Pham-Tuan et. al [33] reported the detection of 4-methoxy-2,2',3,4',5',6 hexachlorobiphenyls (4MeO-PCB149), 3-methylsulfonylPCB149 (3MeSO $2-\mathrm{PCB149),} \mathrm{4-methylsulfonyl-PCB149}$
(4MeSO $2-\mathrm{PCB} 149)$ and 4-methylthionyl-PCB149 (4MeSPCB149) using semipreparative HPLC on $\beta$-cyclodextrinbased columns. However, they found that none of the seven chiral columns evaluated in their study could separate the $4 \mathrm{OH}-\mathrm{PCB} 149$ atropisomers under reversed-phase chromatographic conditions. Only the short Nucleodex $\beta-\mathrm{OH}$, a native $\beta$-cyclodextrin column, gave a hint of an enantioselective separation.

Up to now, there are no successful reports of atropisomeric detection of chiral OH-PCBs by HPLC-MS. In this work, a HPLC-MS method to analyze the atropisomers of five chiral OH-PCBs (4OH-PCB91, 5OH-PCB91, 4OH-PCB95, 5OH-PCB95 and 5OH-PCB149) was developed and the critical parameters were optimized. The method was finally applied to determine the enantiomeric fractions (EFs) of chiral OH-PCBs obtained from incubations of chiral PCBs with rat liver microsomes prepared from phenobarbital (PB)-pretreated male rats. These results of chiral OH-PCBs from LC method were in agreement with an established GCECD method.

\section{Results and discussion \\ Effect of column}

Properties of the chiral column have a great influence on the separation of these chiral OH-PCBs. Four different chiral columns, including Nucleodex $\beta$-PM, Nucleo$\operatorname{dex} \beta-\mathrm{OH}$, Astec Chirobiotic V and LichroCART 250-4 ChiraDex, were used to separate the atropisomers of five chiral OH-PCBs in this work. Nucleodex $\beta-\mathrm{OH}$ column was reported to give a hint of an enantioselective separation of $4 \mathrm{OH}-\mathrm{PCB} 149$ [33], but it never showed any separation of atropisomers of $\mathrm{OH}-\mathrm{PCB} 91, \mathrm{OH}-$ PCB95 and 5OH-PCB149, which suggested that the same chiral column has different enantioselective separation ability for different chiral OH-PCBs. Among the columns studied, only Nucleodex $\beta$-PM column could (partially) separate the atropisomers of $4 \mathrm{OH}-\mathrm{PCB} 91$, 5OH-PCB91, 4OH-PCB95, 5OH-PCB95 and 5OHPCB149 at different operating conditions of the LC-MS. Therefore, Nucleodex $\beta$-PM column was selected for all subsequent experiments.

\section{Effect of column temperature}

The effect of column temperature on the separation of chiral OH-PCBs was studied between $6^{\circ} \mathrm{C}$ to $35^{\circ} \mathrm{C}$ using $4 \mathrm{OH}-\mathrm{PCB} 95$ and $5 \mathrm{OH}-\mathrm{PCB} 95$ as model compounds. While further lowering the column temperature may have improved the atropisomeric separation, temperatures below $6^{\circ} \mathrm{C}$ were considered impractical and not investigated. It can be seen from Figure 1 that the atropisomeric separation performance of $4 \mathrm{OH}-\mathrm{PCB} 95$ and 5OH-PCB95 decreased sharply following the increase of column temperature from $6^{\circ} \mathrm{C}$ to $35^{\circ} \mathrm{C}$. Two 

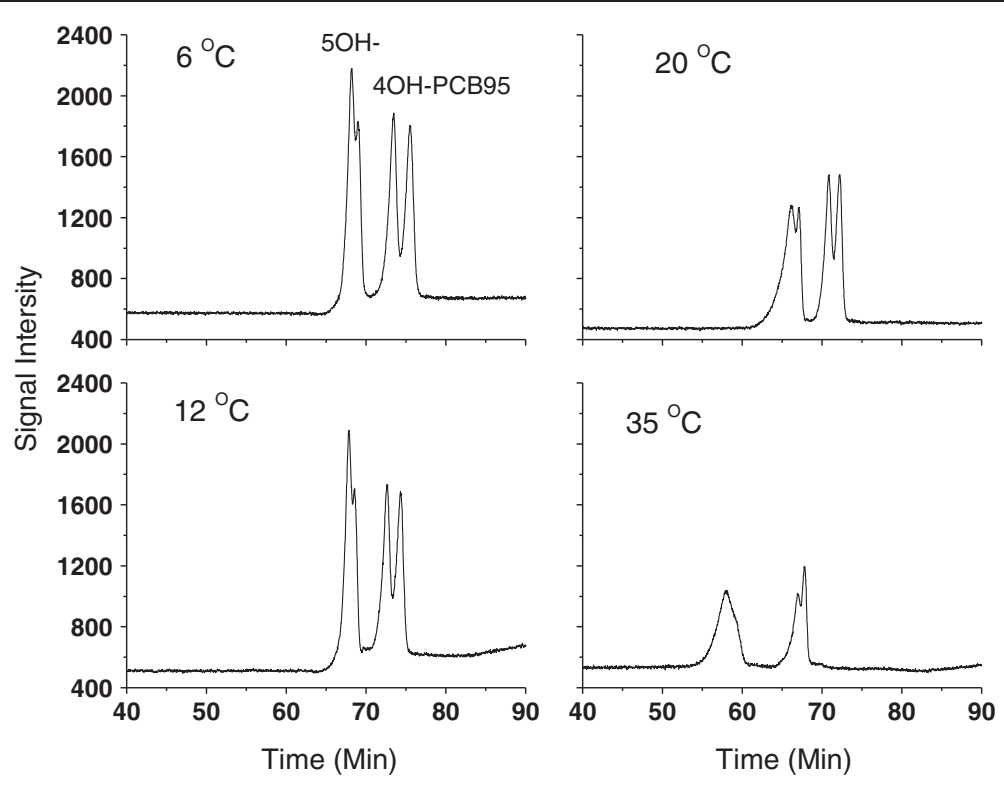

Figure 1 Effect of column temperature on the atropisomeric separation of $10 \mathrm{ng} \mathrm{mL}^{-1}$ of mixture of $40 \mathrm{OH}-\mathrm{PCB} 95$ and $50 \mathrm{OH}-\mathrm{PCB} 95$. Column: Nucleodex $\beta-P M$; Injection: $20 \mu \mathrm{L}$; Mobile Phase: A (water), B (acetonitrile); Gradient: $0 \mathrm{~min}(0.3 \mathrm{~mL} / \mathrm{min}, \mathrm{A}: \mathrm{B}=55: 45) \rightarrow 25 \mathrm{~min}(0.3 \mathrm{~mL} / \mathrm{min}$, $A: B=55: 45) \rightarrow 26 \mathrm{~min}(0.2 \mathrm{~mL} / \mathrm{min}, A: B=50: 50) \rightarrow 55 \mathrm{~min}(0.2 \mathrm{~mL} / \mathrm{min}, A: B=50: 50) \rightarrow 56 \mathrm{~min}(0.2 \mathrm{~mL} / \mathrm{min}, \mathrm{A}: B=45: 55) \rightarrow 65 \mathrm{~min}(0.2 \mathrm{~mL} / \mathrm{min}$, $A: B=45: 55) \rightarrow 66 \mathrm{~min}(0.35 \mathrm{~mL} / \mathrm{min}, A: B=45: 55) \rightarrow 89 \mathrm{~min}(0.35 \mathrm{~mL} / \mathrm{min}, \mathrm{A}: B=45: 55) \rightarrow 90 \mathrm{~min}(0.35 \mathrm{~mL} / \mathrm{min}, \mathrm{A}: B=55: 45) \rightarrow$ Total $100 \mathrm{~min}$.

peaks of 5OH-PCB95 were merged into one peak and the atropisomers of $4 \mathrm{OH}-\mathrm{PCB} 95$ can be slightly separated at $35^{\circ} \mathrm{C}$. Therefore, the column temperature was set at $6^{\circ} \mathrm{C}$ in the subsequent parameter development process. Likewise, Pham-Tuan et al. [33] also found that the enantioselective separation quality of $4 \mathrm{MeO}-$ PCB149 on Nucleodex $\beta$-PM column improved significantly when the column temperature was set at a lower temperature than $35^{\circ} \mathrm{C}$.

\section{Effect of flow rate and ratio of mobile phase}

The composition of the mobile phase and its ratio are very important for the atropisomeric separation of $\mathrm{OH}$ PCBs. Water and acetonitrile were selected as the mobile phase in this work. However, only a narrow ratio range (50-60\% of acetonitrile) was confirmed to separate the $\mathrm{OH}-\mathrm{PCB}$ atropisomers with much testing. These chiral $\mathrm{OH}-\mathrm{PCBs}$ were hard to elute when the ratio of acetonitrile was below 50\% and they eluted together when ratio of acetonitrile was above $60 \%$. In addition, it was found that a gradient mobile phase can separate them better than isocratic conditions. Therefore, gradient mobile phase conditions were optimized in the following experiment. It can be seen from Figure 2 that condition III in Table 1 had the best separation for 4OH-PCB95 and 5OH-PCB95. Under this condition III, other OH-PCB atropisomers also displayed good separation as shown in Figure 3.

\section{Analytical performance}

The analytical performance data of this optimized HPLCMS method for the atropisomers of five chiral OH-PCBs are shown in Table 2. Linear calibration curves, based on peak areas to concentration, were obtained in the range of $1.0-100.0 \mathrm{ng} \mathrm{mL} \mathrm{m}^{-1}$, with correlation coefficients ranging

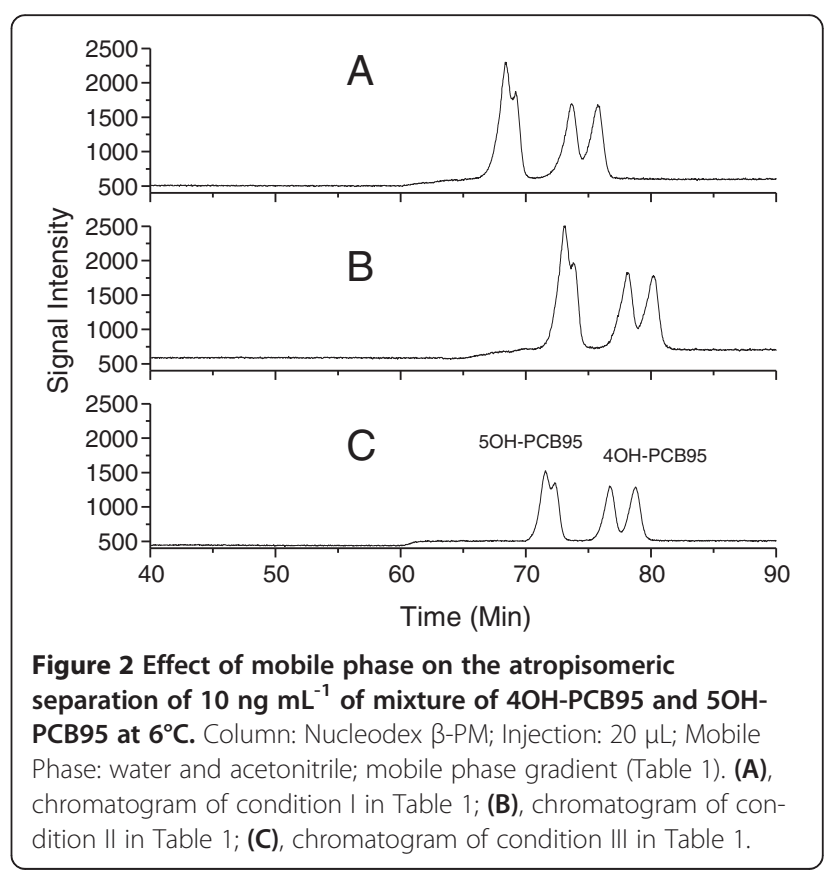


Table 1 Time table of gradient mobile phases in Figure 2: A (water), B (acetonitrile)

\begin{tabular}{ll}
\hline Condition & Time table of gradient mobile phases \\
\hline I & $0 \min (0.3 \mathrm{~mL} / \mathrm{min}, A: B=55: 45) \rightarrow 25 \mathrm{~min}(0.3 \mathrm{~mL} / \mathrm{min}, A: B=55: 45) \rightarrow 26 \mathrm{~min}(0.2 \mathrm{~mL} / \mathrm{min}, A: B=50: 50) \rightarrow 55 \mathrm{~min}(0.2 \mathrm{~mL} / \mathrm{min}$, \\
& $A: B=50: 50) \rightarrow 56 \mathrm{~min}(0.2 \mathrm{~mL} / \mathrm{min}, A: B=45: 55) \rightarrow 65 \mathrm{~min}(0.2 \mathrm{~mL} / \mathrm{min}, A: B=45: 55) \rightarrow 66 \mathrm{~min}(0.35 \mathrm{~mL} / \mathrm{min}, A: B=45: 55) \rightarrow 89 \mathrm{~min}$ \\
& $(0.35 \mathrm{~mL} / \mathrm{min}, A: B=45: 55) \rightarrow 90 \min (0.35 \mathrm{~mL} / \mathrm{min}, A: B=55: 45) \rightarrow$ Total $100 \mathrm{~min}$ \\
& $0 \min (0.2 \mathrm{~mL} / \mathrm{min}, A: B=55: 45) \rightarrow 25 \mathrm{~min}(0.2 \mathrm{~mL} / \mathrm{min}, A: B=55: 45) \rightarrow 26 \mathrm{~min}(0.2 \mathrm{~mL} / \mathrm{min}, A: B=50: 50) \rightarrow 55 \mathrm{~min}(0.2 \mathrm{~mL} / \mathrm{min}$, \\
& $A: B=50: 50) \rightarrow 56 \mathrm{~min}(0.2 \mathrm{~mL} / \mathrm{min}, A: B=45: 55) \rightarrow 65 \mathrm{~min}(0.2 \mathrm{~mL} / \mathrm{min}, A: B=45: 55) \rightarrow 66 \mathrm{~min}(0.35 \mathrm{~mL} / \mathrm{min}, A: B=45: 55) \rightarrow 89 \mathrm{~min}$ \\
& $(0.35 \mathrm{~mL} / \mathrm{min}, A: B=45: 55) \rightarrow 90 \mathrm{~min}(0.35 \mathrm{~mL} / \mathrm{min}, A: B=55: 45) \rightarrow$ Total $100 \mathrm{~min}$ \\
& $0 \min (0.2 \mathrm{~mL} / \mathrm{min}, A: B=55: 45) \rightarrow 25 \mathrm{~min}(0.2 \mathrm{~mL} / \mathrm{min}, A: B=55: 45) \rightarrow 26 \mathrm{~min}(0.2 \mathrm{~mL} / \mathrm{min}, A: B=50: 50) \rightarrow 55 \mathrm{~min}(0.2 \mathrm{~mL} / \mathrm{min}$, \\
& $A: B=50: 50) \rightarrow 56 \mathrm{~min}(0.2 \mathrm{~mL} / \mathrm{min}, A: B=45: 55) \rightarrow 60 \mathrm{~min}(0.2 \mathrm{~mL} / \mathrm{min}, A: B=45: 55) \rightarrow 61 \mathrm{~min}(0.35 \mathrm{~mL} / \mathrm{min}, A: B=45: 55) \rightarrow 89 \mathrm{~min}$ \\
& $(0.35 \mathrm{~mL} / \mathrm{min}, A: B=45: 55) \rightarrow 90 \mathrm{~min}(0.35 \mathrm{~mL} / \mathrm{min}, A: B=55: 45) \rightarrow$ Total $100 \mathrm{~min}$ \\
\hline
\end{tabular}

from 0.9996 to 0.9999 for all $\mathrm{OH}-\mathrm{PCB}$ atropisomers. The relative standard deviations measured at the $10.0 \mathrm{ng} \mathrm{mL}^{-1}$ level for $\mathrm{OH}-\mathrm{PCB}$ atropisomers were in the range of 0.60 $7.55 \%(n=5)$. Calculated detection limits $(S / N=3)$ of five chiral $\mathrm{OH}-\mathrm{PCBs}$ were between 0.31 and $0.60 \mathrm{ng} \mathrm{mL}^{-1}$ for all $\mathrm{OH}-\mathrm{PCB}$ atropisomers. Thus, the method developed in this work had a relatively high sensitivity and low detection limit. The detection limits of the $\mathrm{OH}-\mathrm{PCBs}$ in the GC-ECD method were considerably higher and ranged from 19.0 to $27.6 \mathrm{ng} \mathrm{mL} \mathrm{m}^{-1}$.

\section{Determination of chiral OH-PCBs in PB induced rat liver microsomal samples}

Though PCBs are a group of persistent organic pollutants, many PCB congenrs can be metabolized by a series of enzymes in biota. Hydroxylated metabolites of PCBs are a group of important metabolites and have been frequently reported in biota $[28,29,34]$. Rat liver microsomes are a powerful tool to study the metabolism of
PCBs and generate atropisomerically enriched $\mathrm{OH}-\mathrm{PCBs}$ [32]. The newly developed HPLC-MS method was applied to the determination of the atropisomers of the hydroxylated metabolites of chiral PCB91, PCB95 and PCB149 formed by liver microsomes from $\mathrm{PB}$-treated rats. Furthermore, a large amount of these chiral OH-PCBs were produced from chiral PCBs by $\mathrm{PB}$ induced rat liver microsomes, reaching $\mu \mathrm{g} \mathrm{mL}^{-1}$ level. It can be seen from Table 3 that good spiked recoveries (\%) of $4 \mathrm{OH}-\mathrm{PCB} 159$ in these samples ranged from $82.3 \pm 4.3$ to $96.5 \pm 9.0$ in LC-MS method. In addition, 5OH-PCB91, 95 and 149 were detected with high concentrations and no $4 \mathrm{OH}-\mathrm{PCB}$ 91, 95 and 149 were found, which suggested that liver microsomes for PB-pretreated rats preferentially produce para-position hydroxylated metabolites of these chiral PCBs. More interestingly, these chiral 5OH-PCBs were formed enantioselectively. It can be seen from Figure 4 and Table 3 that the second eluent (E2) of 5OH-PCB91 and the first eluent (E1) of 5OH-PCB149 were enriched,

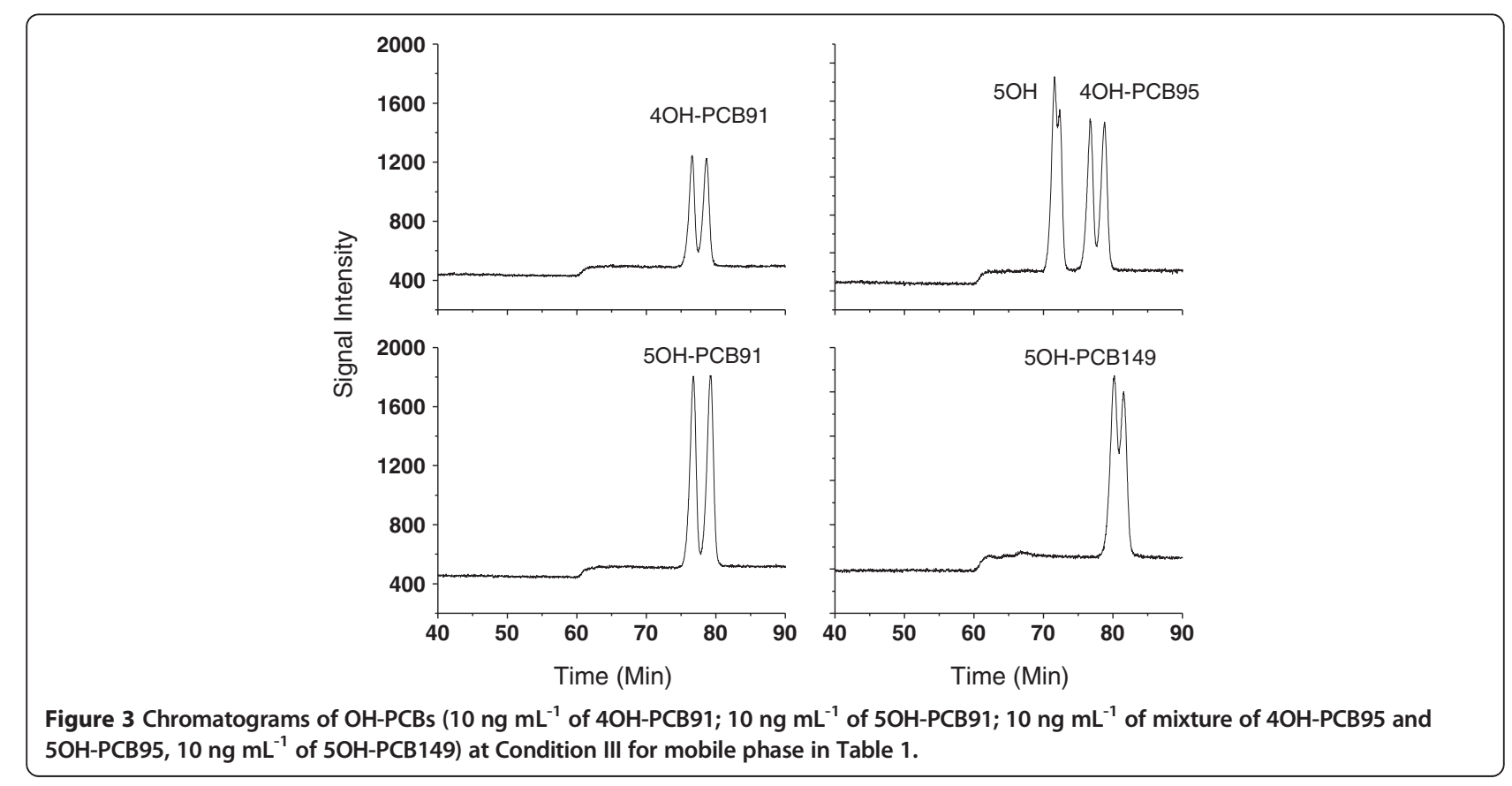


Table 2 The analytical performance data of the proposed LC-MS method

\begin{tabular}{|c|c|c|c|c|}
\hline Compound & Calibration curve & $\begin{array}{l}\text { Correlation } \\
\text { coefficient }\end{array}$ & $\begin{array}{l}\text { Detection limit } \\
\left(\mathrm{ng} \mathrm{mL} \mathrm{mL}^{-1}\right)\end{array}$ & $\begin{array}{l}\text { RSD } \\
(\%, n=5)^{a}\end{array}$ \\
\hline E1-5OH-PCB91 & $Y=8697.4 \times-2090.9$ & 0.9998 & 0.30 & 1.31 \\
\hline E2-5OH-PCB91 & $Y=9261.9 x-2124.1$ & 0.9997 & 0.31 & 0.60 \\
\hline E1-4OH-PCB91 & $Y=4831.3 x-1493.0$ & 0.9998 & 0.54 & 0.67 \\
\hline E2-4OH-PCB91 & $Y=5009.9 x-1607.8$ & 0.9998 & 0.60 & 1.14 \\
\hline E1-5OH-PCB95 & $Y=6172.1 \times-3904.2$ & 0.9997 & 0.44 & 7.55 \\
\hline E2-5OH-PCB95 & $Y=3822.2 x-2213.2$ & 0.9996 & 0.56 & 6.87 \\
\hline E1-4OH-PCB95 & $Y=5275.7 \times-1726.8$ & 0.9998 & 0.49 & 3.12 \\
\hline E2-4OH-PCB95 & $Y=5371.7 \times-1728.8$ & 0.9997 & 0.55 & 3.45 \\
\hline E1-5OH-PCB149 & $Y=6502.2 x-2647.4$ & 0.9998 & 0.53 & 0.99 \\
\hline E2-5OH-PCB149 & $Y=4969.6 x-624.2$ & 0.9999 & 0.60 & 3.37 \\
\hline
\end{tabular}

${ }^{\mathrm{a}}$, All standard concentration, $10.0 \mathrm{ng} \mathrm{mL}^{-1}$.

with EFs being $0.183 \pm 0.002$ for $5 \mathrm{OH}-\mathrm{PCB} 91$, and $0.731 \pm 0.007$ for $5 \mathrm{OH}-\mathrm{PCB} 149$. However, only E2-OHPCB95 was found in HPLC-MS method.

In order to confirm the validity of LC-MS method for the atropisomers of these chiral OH-PCBs, the samples were also analyzed by GC-ECD method with derivatization on chiral and achiral columns. Results showed that the EFs and each mass of the atropisomers were highly consistent in LC and GC methods. For example, EFs were $0.188 \pm 0.001$ for $5 \mathrm{OH}-\mathrm{PCB} 91$ and $0.704 \pm 0.003$ for $5 \mathrm{OH}-$ PCB 149 for the GC method and EFs were $0.183 \pm 0.002$ for $5 \mathrm{OH}-\mathrm{PCB} 91$ and $0.731 \pm 0.007$ for $5 \mathrm{OH}-\mathrm{PCB} 149$ for LC method, respectively. In addition, the total mass of $\mathrm{OH}-\mathrm{PCBs}$ on a GC chiral and achiral column also matched well the total mass on LC-MS column. The total mass of $5 \mathrm{OH}-\mathrm{PCB} 91$ was $1.670 \pm 0.079 \mu \mathrm{g} \mathrm{mL}$

Table 3 Comparison of OH-PCBs atropisomer levels and enantiomeric fractions (EF) determined by LC-MS and GC-ECD methods

\begin{tabular}{|c|c|c|c|c|}
\hline \multirow[t]{2}{*}{ Sample } & \multirow[t]{2}{*}{ Congener } & \multirow{2}{*}{$\begin{array}{l}\text { LC-MS } \\
\text { Nucleodex } \beta \text {-PM }\end{array}$} & \multirow{2}{*}{$\begin{array}{l}\text { GC-ECD } \\
\text { BDM chiral column }\end{array}$} & \multirow{2}{*}{$\begin{array}{l}\text { GC-ECD } \\
\text { DB1 achiral column }\end{array}$} \\
\hline & & & & \\
\hline \multirow{6}{*}{ PCB91 } & E1-5OH-PCB91 $\left(\mu \mathrm{g} \mathrm{mL}^{-1}\right)$ & $0.306 \pm 0.011$ & $0.268 \pm 0.006$ & \multirow[t]{4}{*}{$1.334 \pm 0.023$} \\
\hline & E2-5OH-PCB91 $\left(\mu \mathrm{g} \mathrm{mL}^{-1}\right)$ & $1.364 \pm 0.068$ & $1.160 \pm 0.038$ & \\
\hline & Total $\left(\mu \mathrm{g} \mathrm{mL}^{-1}\right)$ & $1.670 \pm 0.079$ & $1.428 \pm 0.044$ & \\
\hline & EF (5OH-PCB91) & $0.183 \pm 0.002$ & $0.188 \pm 0.001$ & \\
\hline & 4OH-PCB91 & ND & ND & $0.013 \pm 0.001$ \\
\hline & Recovery of $4 \mathrm{OH}-\mathrm{PCB} 159$ (\%) & $82.3 \pm 4.3$ & $97.3 \pm 1.7$ & $99.9 \pm 3.6$ \\
\hline \multirow{6}{*}{ PCB95 } & E1-5OH-PCB95 $\left(\mu \mathrm{g} \mathrm{mL}^{-1}\right)$ & ND & $0.262 \pm 0.014$ & \multirow{4}{*}{$1.183 \pm 0.068$} \\
\hline & E2-5OH-PCB95 $\left(\mu \mathrm{g} \mathrm{mL}^{-1}\right)$ & $1.346 \pm 0.345$ & $0.789 \pm 0.042$ & \\
\hline & Total $\left(\mu \mathrm{g} \mathrm{mL}^{-1}\right)$ & $1.346 \pm 0.345$ & $1.051 \pm 0.057$ & \\
\hline & $\mathrm{EF}(5 \mathrm{OH}-\mathrm{PCB95})$ & & $0.249 \pm 0.001$ & \\
\hline & 4OH-PCB95 & ND & ND & $0.007 \pm 0.002$ \\
\hline & Recovery of $4 \mathrm{OH}-\mathrm{PCB} 159$ (\%) & $96.5 \pm 9.0$ & $106.6 \pm 11.4$ & $101.5 \pm 9.1$ \\
\hline \multirow{5}{*}{ PCB149 } & E1-5OH-PCB149 $\left(\mu \mathrm{g} \mathrm{mL}^{-1}\right)$ & $0.913 \pm 0.079$ & $0.648 \pm 0.019$ & \multirow[t]{4}{*}{$1.281 \pm 0.050$} \\
\hline & E2-5OH-PCB149 $\left(\mu \mathrm{g} \mathrm{mL}^{-1}\right)$ & $0.335 \pm 0.029$ & $0.272 \pm 0.009$ & \\
\hline & Total $\left(\mu \mathrm{g} \mathrm{mL}^{-1}\right)$ & $1.248 \pm 0.108$ & $0.920 \pm 0.028$ & \\
\hline & $\mathrm{EF}(5 \mathrm{OH}-\mathrm{PCB} 149)$ & $0.731 \pm 0.007$ & $0.704 \pm 0.003$ & \\
\hline & Recovery of $4 \mathrm{OH}-\mathrm{PCB} 159$ (\%) & $88.6 \pm 0.7$ & $113.8 \pm 1.9$ & $115.4 \pm 1.2$ \\
\hline \multirow{2}{*}{ Blank control } & Any $\mathrm{OH}-\mathrm{PCBs}$ & ND & ND & ND \\
\hline & Recovery of $4 \mathrm{OH}-\mathrm{PCB} 159$ (\%) & 92.5 & - & 111 \\
\hline
\end{tabular}

ND: not detected. 


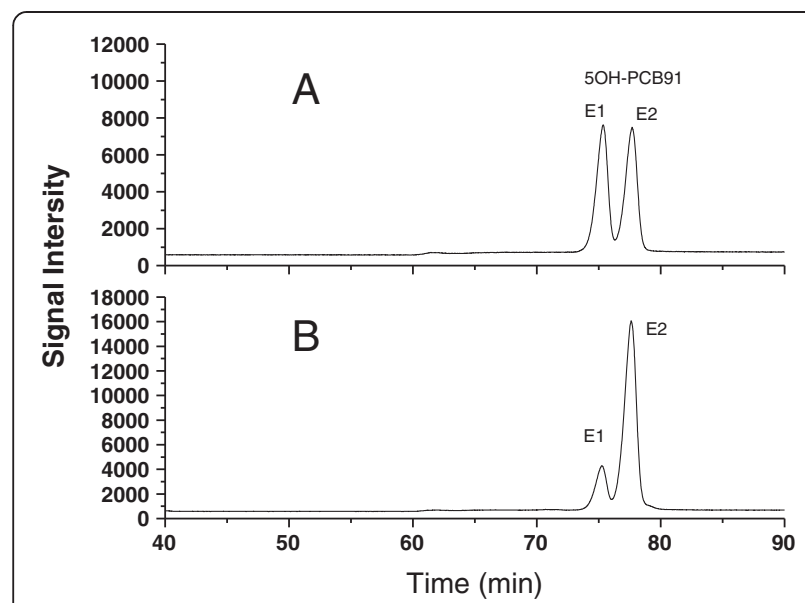

\section{I: OH-PCB91}

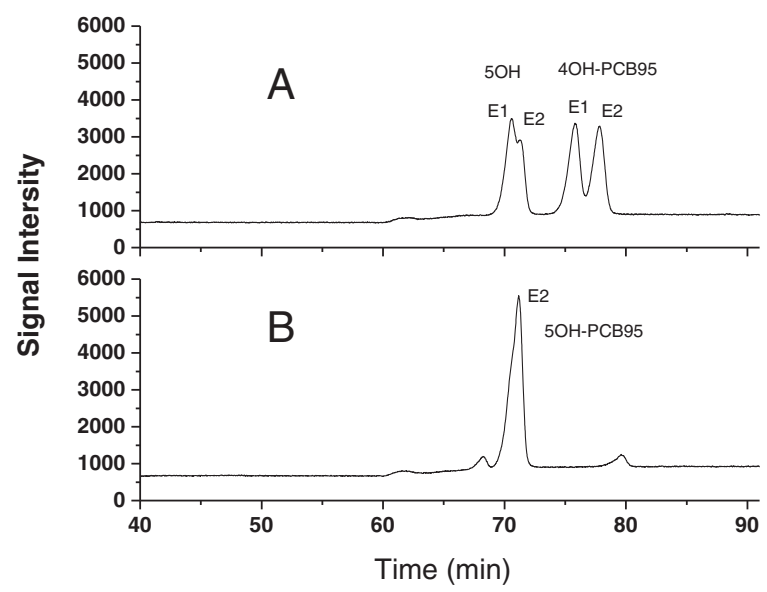

III: OH-PCB95

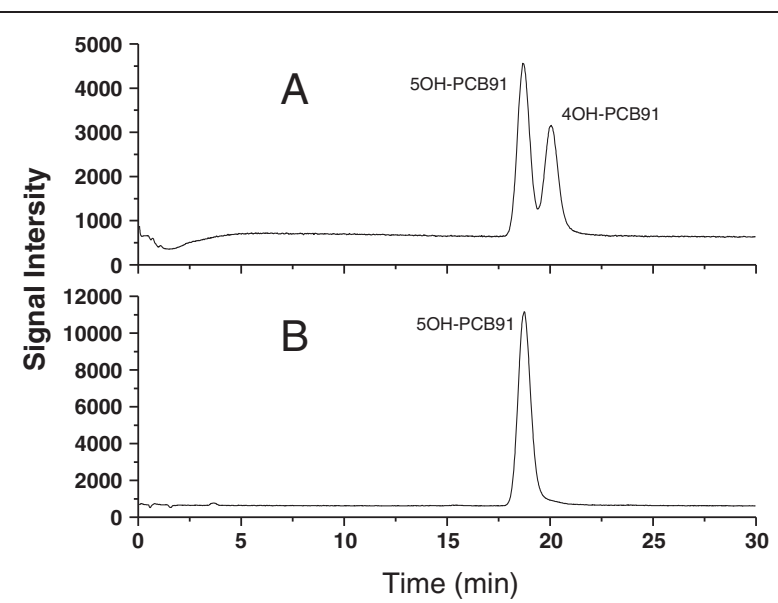

II: OH-PCB91 on achiral column (C18)

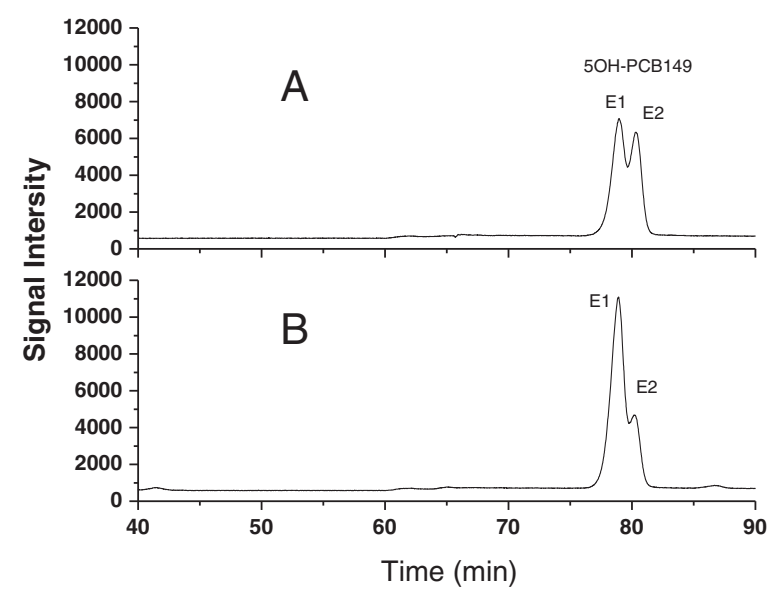

IV: OH-PCB149

Figure 4 Chromatograms of $\mathrm{OH}-\mathrm{PCBs}$ formed in in rat liver microsomal incubations (B) and their relevant standards (A).

for HPLC-MS method; the total masses of 5OH-PCB91 were $1.428 \pm 0.044 \mu \mathrm{g} \mathrm{mL}^{-1}$ and $1.334 \pm 0.023 \mu \mathrm{g} \mathrm{mL}^{-1}$ on chiral and achiral column for GC-ECD method. However, 5OH-PCB 95 showed the difference because chiral LC column cannot separate two atropisomers of $5 \mathrm{OH}-\mathrm{PCB}$ 95 well and the atropisomer of lower concentration (E1) is off-set by the E2 with higher concentration. Therefore, chiral HPLC columns with improved resolution for chiral $\mathrm{OH}-\mathrm{PCBs}$ should be the subject of research in the future. In addition, a trace amount of $4 \mathrm{OH}-\mathrm{PCB} 91$ and $4 \mathrm{OH}-$ PCB95 (less than 1\% mass ratio of their $5 \mathrm{OH}-\mathrm{PCB} 91$ and 5OH-PCB95) were found on achiral column of GC-ECD method but not on chiral LC and GC methods.

\section{Experimental}

\section{Materials}

The chemical structures of five chiral OH-PCBs $(4 \mathrm{OH}-$ PCB91, 5OH-PCB91, 4OH-PCB95, 5OH-PCB95 and $5 \mathrm{OH}-\mathrm{PCB} 149 ; 98 \%$ purity or better) are shown in
Figure 5. They were synthesized by the Synthesis Core of the Iowa Superfund Research Program at the University of Iowa using established procedures $[35,36]$. The recovery standard, 4OH-PCB159 from AccuStandard was used for LC and GC methods. The internal standards, PCB166 and PCB204, for GC analyses were obtained from AccuStandard (New Haven, CT, USA). Stock solutions of these OH-PCBs $\left(1.0 \mathrm{mg} \mathrm{mL}^{-1}\right)$ were prepared in acetonitrile. Working solutions of these $\mathrm{OH}-\mathrm{PCBs}$ were prepared by gradual dilution of the stock solution with acetonitrile. All standards and solutions of these $\mathrm{OH}-\mathrm{PCB}$ sere stored hermetically in amber glass vials at $4^{\circ} \mathrm{C}$.

Acetonitrile was HPLC grade and hexane, 2-propanol and methyl tert-butyl ether (MTBE) were pesticide grade solvents purchased from Fisher Scientific (Pittsburgh, $\mathrm{PA})$. The deionized water (18.2 $\mathrm{M} \Omega$ ) was from an ultrapure water system (Barnstead International, Dubuque, IA, USA). All other chemicals and reagents used in this experiment were of analytical reagent grade or better. 


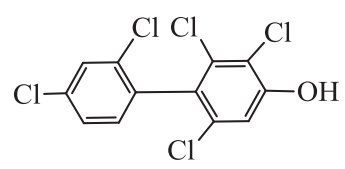

4OH-PCB91

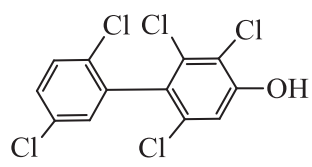

4OH-PCB95

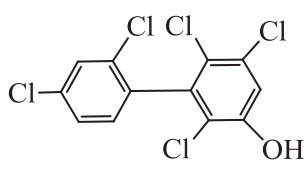

5OH-PCB91

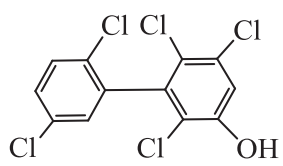

5OH-PCB95

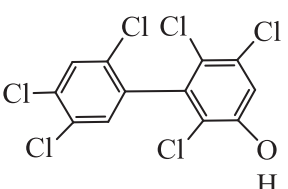

5OH-PCB149

Figure 5 Structures of five chiral OH-PCBs.

\section{LC-MS method}

Qualitative and quantitative analysis of chiral OH-PCBs was performed on HPLC-MS (Agilent 1100 Series LC/MSD) with an autosampler. Sample separation was optimized using Nucleodex $\beta$-PM $(4 \mathrm{~mm} \times 200 \mathrm{~mm}, 5 \mu \mathrm{m})$ and Nucleodex $\beta-\mathrm{OH}(4 \mathrm{~mm} \times 200 \mathrm{~mm}, 5 \mu \mathrm{m})$ from MachereyNagel, Germany; Astec Chirobiotic V (4.6 mm $\times 250 \mathrm{~mm}$, $5 \mu \mathrm{m})$ from Sigma-Aldrich; LichroCART 250-4 ChiraDex $(4 \mathrm{~mm} \times 250 \mathrm{~mm}, 5 \mu \mathrm{m})$ from Merck; Agilent SB-C18 $(2.1 \times 50 \mathrm{~mm}, 1.8 \mu \mathrm{m})$. The mobile phase was acetonitrile and water with isocratic conditions. The injection volume of each column was $20 \mu \mathrm{l}$ except for Agilent SB-C18 $(5 \mu \mathrm{l})$. MS electrospray in negative ionization mode (LC-ESI (-)-MS) was utilized. Other operating conditions were: Selected Ion Monitoring (SIM) Ion Mass: $m / z 341$ for $\mathrm{OH}-\mathrm{PCB} 91$ and OH-PCB95; $\mathrm{m} / z 375$ for OH-PCB149 and $\mathrm{OH}-\mathrm{PCB} 159$; Fragmentor: $100 \mathrm{~V}$; Capillary Voltage: 4000 V; Gain: 7.00; Drying Gas Flow: $10 \mathrm{~L} \mathrm{~min}^{-1}$; Nebulizer Pressure: 35 psi; Drying Gas Temperature: $250^{\circ} \mathrm{C}$.

\section{GC-ECD methods}

Analysis of the methylated derivatives of OH-PCBs was carried out using an Agilent $6890 \mathrm{~N}$ gas chromatograph equipped with a ${ }^{63} \mathrm{Ni}-\mu \mathrm{ECD}$ detector and a DB1-MS capillary column $(60 \mathrm{~m} \times 0.25 \mathrm{~mm}$ ID $\times 0.25 \mu \mathrm{m}$ film thickness; Agilent, Santa Clara, CA, USA) [32]. The injector and detector temperatures were $280^{\circ} \mathrm{C}$ and $300^{\circ} \mathrm{C}$, respectively. The temperature program was as follows: $100^{\circ} \mathrm{C}$ for $1 \mathrm{~min}, 5^{\circ} \mathrm{C} / \mathrm{min}$ to $250^{\circ} \mathrm{C}$, hold for $20 \mathrm{~min}$, $5^{\circ} \mathrm{C} / \mathrm{min}$ to $280^{\circ} \mathrm{C}$, hold for $3 \mathrm{~min}$. Helium was used as the carrier gas with a flow rate of $1 \mathrm{~mL} / \mathrm{min}$. Concentrations of $\mathrm{OH}-\mathrm{PCB}$ metabolites were determined using PCB 166 or PCB 204 as internal standards. The detection limits (LODs) of the $\mathrm{OH}-\mathrm{PCBs}$, calculated from the standard deviation (SD) of the response and the slope of the calibration curve $(S)$ using the formula $\mathrm{LOD}=3.3(\mathrm{SD} / \mathrm{S}) \quad[37]$, were $22.1 \mathrm{ng} \mathrm{mL}^{-1}$,
$23.0 \mathrm{ng} \mathrm{mL}{ }^{-1}, 19.0 \mathrm{ng} \mathrm{mL} \mathrm{m}^{-1}, 27.6 \mathrm{ng} \mathrm{mL}^{-1}$ and $26.6 \mathrm{ng} \mathrm{mL}^{-1}$ for $5 \mathrm{OH}-\mathrm{PCB} 91,4 \mathrm{OH}-\mathrm{PCB} 91,5 \mathrm{OH}-\mathrm{PCB} 95,4 \mathrm{OH}-\mathrm{PCB}$ 95 and 5OH-PCB 149, respectively.

Enantioselective analysis was performed using an Agilent $7890 \mathrm{~A}$ gas chromatograph equipped with ${ }^{63} \mathrm{Ni}$ $\mu \mathrm{ECD}$ detector as described previously [31]. The injector and detector temperatures were kept at $250^{\circ} \mathrm{C}$. The atropisomers of five chiral $\mathrm{OH}-\mathrm{PCBs}$ were separated using a ChiralDex BDM column $(30 \mathrm{~m} \times 250 \mu \mathrm{m} \times 0.12 \mu \mathrm{m}$; Supelco, Analytical, St. Louis, MO). The temperature program was as follows: $100^{\circ} \mathrm{C}$ for $1 \mathrm{~min}, 10^{\circ} \mathrm{C} / \mathrm{min}$ to $148^{\circ} \mathrm{C}$, hold for $400 \mathrm{~min}, 10^{\circ} \mathrm{C} / \mathrm{min}$ to $200^{\circ} \mathrm{C}$, hold for $13 \mathrm{~min}$. The flow rate of the carrier gas (helium) was $3 \mathrm{~mL} / \mathrm{min}$.

\section{Calculation of enantiomeric fractions}

Enantiomer fraction or enantiomeric fraction (EF) was used to calculate the atropisomer composition in this work: $\mathrm{EF}=\mathrm{C}_{\mathrm{E} 1} /\left(\mathrm{C}_{\mathrm{E} 1}+\mathrm{C}_{\mathrm{E} 2}\right)$.

where $C_{E 1}$ and $C_{E 2}$ are the concentrations $(C)$ of the first-eluting enantiomer (E1) and the second-eluting enantiomer (E2) on the chiral chromatographic column.

\section{Microsomal metabolism experiments}

Experiments involving animals were approved by the Institutional Animal Care and Use Committee at the University of Iowa. Liver microsomes were prepared from phenobarbital-pretreated male Spargue-Dawley rats and microsomal metabolism experiments were performed as described elsewhere [32]. Briefly, an incubation mixture (16 $\mathrm{mL}$ final volume) consisting of phosphate buffer (0.1 M, pH 7.4), nicotinamide adenine dinucleotide phosphate hydrogen (NADPH) $(0.5 \mathrm{mM})$, magnesium chloride (3 $\mathrm{mM})$, and hepatic microsomal protein $(0.75 \mathrm{mg} / \mathrm{mL})$ was pre-incubated for $5 \mathrm{~min}$ at $37 \pm 1^{\circ} \mathrm{C}$ in a shaking water bath. PCB 91, PCB95 or PCB149 were added to initiate the reactions, with a final concentration at $50 \mu \mathrm{M}$. 
Ten $\mathrm{mL}$ of ice cold sodium hydroxide $(0.5 \mathrm{M})$ were added to stop the reaction after $30 \mathrm{~min}$ incubation. Control incubations without PCBs were performed in parallel. Extraction of each PCB and its hydroxylated metabolites was performed using a published method [32]. Surrogate standard (1370 ng of 4OH-PCB 159) was added to each sample, followed by hydrochloric acid $(6 \mathrm{M}, 5 \mathrm{~mL})$ and 2-propanol $(15 \mathrm{~mL})$. The samples were extracted with hexane-MTBE $(1: 1 \mathrm{v} / \mathrm{v}, 25 \mathrm{~mL})$ and hexane $(15 \mathrm{~mL})$. The combined organic extracts were washed with an aqueous $\mathrm{KCl}$ solution $(1 \%, 15 \mathrm{~mL})$. After removal of the organic phase, the $\mathrm{KCl}$ phase was re-extracted with hexane $(15 \mathrm{~mL})$, and the combined extracts were reduced under a gentle stream of nitrogen to dryness. The residue was redissolved in $3 \mathrm{~mL}$ of hexane and divided by weight into two parts for LC-MS and GCECD analysis. The samples were blown to dryness under a gentle stream of nitrogen and then redissolved in acetonitrile for LC-MS analysis. For GC analysis, the hydroxylated metabolites were derivatized with diazomethane and subjected to a sulfur cleanup step prior to analysis as described previously [25].

\section{Conclusions}

A novel HPLC-MS method was developed and successfully applied to measure chiral OH-PCB levels and EFs in rat liver microsomal samples. The method can easily detect chiral OH-PCBs without derivatization. The results of OH-PCB atropisomers from LC-MS were consistent with those from GC-ECD method, which confirm the validity of LC-MS method for the determination of $\mathrm{OH}-\mathrm{PCB}$ atropisomers. It is the first report of chiral OH-PCBs detected by HPLC-MS. The proposed method should be applicable to detect chiral OH-PCBs in environmental samples and metabolic mechanisms of PCBs as well as rat microsomes.

\section{Competing interests}

The authors declare that they have no competing interests.

\section{Authors' contributions}

GZ and XW performed the experiments and drafted the manuscript. $\mathrm{HL}$ and JS participated in the conception, design of study and revision of the manuscript. All authors read and approved the final manuscript.

\section{Acknowledgment}

This work was supported by the lowa Superfund Basic Research Program (SBRP), National Institute of Environmental Health Science, Grant Number P42ES013661. We also thank the Center for Global and Regional Environmental Research (CGRER) for support of this work and the W.M. Keck Phytotechnologies Laboratory at the University of lowa.

Received: 25 September 2013 Accepted: 16 December 2013 Published: 22 December 2013

\section{Reference}

1. Safe SH: Polychlorinated biphenyls (PCBs): environmental impact, biochemical and toxic responses, and implications for risk assessment. Crit Rev Toxicol 1994, 24:87-149.
2. Evans MS, Noguchi GE, Rice CP: The biomagnifications of polychlorinated biphenyls, toxaphene, and DDT compounds in a Lake Michigan offshore food web. Arch Environ Contam Toxicol 1991, 20:87-93.

3. Kaiser K: On the optical activity of polychlorinated biphenyls. Environ Pollut 1974, 7:93-101.

4. Frame GM, Wagner RE, Carnahan JC, Brown JF Jr, May RJ, Smullen LA, Bedard DL: Comprehensive, quantitative congener-specific analyses of eight Aroclors and complete PCB congener assignments on DB-1 capillary GC columns. Chemosphere 1996, 33(4):603-623.

5. Robson M, Harrad S: Chiral PCB signatures in air and soil: Implications for atmospheric source apportionment. Environ Sci Technol 2004, 38:1662-1666.

6. Wong F, Robson M, Diamond M, Harrad S, Truong J: Concentrations and chiral signatures of POPs in soil and sediments: a comparative urban versus rural study in Canada and UK. Chemosphere 2009, 74:404-411.

7. Wong CS, Garrison AW, Foreman WT: Enantiomeric composition of chiral polychlorinated biphenyl atropisomers in aquatic bed sediment. Environ Sci Technol 2001, 35:33-39.

8. Wong CS, Garrison AW, Smith PD, Foreman WT: Enantiomeric composition of chiral polychlorinated biphenyl atropisomers in aquatic and riparian biota. Environ Sci Technol 2001, 35:2448-2454.

9. Ross MS, Verreault J, Letcher RJ, Gabrielsen GW, Wong CS: Chiral organochlorine contaminants in blood and eggs of glaucous gulls (Larus hyperboreus) from the Norwegian Arctic. Environ Sci Technol 2008, 42:7181-7186.

10. Serrano R, Fernandez M, Rabanal R, Hernandez LM, Gonzalez MJ: Congener-specific determination of polychlorinated biphenyls in shark and grouper livers from the Northwest African Atlantic Ocean. Arch Environ Contam Toxicol 2000, 38:217-224.

11. Reich $S$, Jimenez B, Marsili L, Hernández LM, Schurig V, González MJ: Congener specific determination and enantiomeric ratios of chiral polychlorinated biphenyls in striped dolphins (Stenella coeruleoalba) from the Mediterranean Sea. Environ Sci Technol 1999, 33:1787-1793.

12. Hoekstra PF, Wong CS, O'Hara TM, Solomon KR, Mabury SA, Muir DCG: Enantiomer-specific accumulation of PCB atropisomers in the bowhead whale (Balaena mysticetus). Environ Sci Technol 2002, 36:1419-1425.

13. Harrad S, Ren J, Hazrati S, Robson M: Chiral signatures of PCB\#s 95 and 149 in indoor air, grass, duplicate diets and human faeces. Chemosphere 2006, 63:1368-1376.

14. Chu S, Covaci A, Schepens P: Levels and chiral signatures of persistent organochlorine pollutants in human tissues from Belgium. Environ Res 2003, 93:167-176

15. Lehmler H-J, Harrad SJ, Hunerfuss H, Kania-Korwel I, Lee CM, Lu Z, Wong CS: Chiral polychlorinated biphenyl transport, metabolism, and distribution: a review. Environ Sci Technol 2010, 44:2757-2766.

16. Nezel T, Muller-Plathe F, Muller MD, Buser H-R: Theoretical considerations about chiral PCBs and their methylthio and methylsulfonyl metabolites being possibly present as stable enantiomers. Chemosphere 1997, 35:1895-1906.

17. Park J, Linderholm L, Charles MJ, Athanasiadou M, Petrik J, Kocan A, Drobna B, Trnovec T, Bergman A, Hertz-Picciotto I: Polychlorinated biphenyls and their hydroxylated metabolites (OH-PCBs) in pregnant women from eastern Slovakia. Environ Health Perspect 2007, 115:20-27.

18. Bergman A, Klasson-Wehler $\mathrm{E}$, Kuroki H: Selective retention of hydroxylated PCB metabolites in blood. Environ Health Perspect 1994, 102:464-469.

19. Preston $\mathrm{BD}$, Allen JR: 2,2',5,5'-tetrachlorobiphenyl: isolation and identification of metaboliltes generated by rat liver microsomes. Drug Metabol Dispos 1980, 4:197-204.

20. Rezek J, Macek T, Mackova M, Triska J: Plant metabolites of polychlorinated biphenyls in hairy root culture of black nightshade Solanum nigrum SNC-90. Chemosphere 2007, 69:1221-1227.

21. Fangstrom B, Athanasiadou M, Grandjean P, Weihe P, Bergman A: Hydroxylated PCB metabolites and PCBs in serum from pregnant faroese women. Environ Health Perspect 2002, 110:895-899.

22. Hovander L, Malmberg T, Athanasiadou M, Athanassiadis I, Rahm S, Bergman A, Wehler EK: Identification of hydroxylated PCB metabolites and other phenolic pollutants in halogenated human blood plasma. Arch Environ Contam Toxicol 2002, 42:105-117.

23. Fujihiro S, Higuchi R, Hisamatsu S, Sonoki S: Metabolism of hydroxylated PCB congeners by cloned laccase isoforms. Appl Microbiol Biotechnol 2009, 82:853-860 
24. Kania-Korwel I, Vyas SM, Song Y, Lehmler H-J: Gas chromatographic separation of methoxylated polychlorinated biphenyl atropisomers. J Chromatogr A 2008, 1207:146-154.

25. Kania-Korwel I, Zhao H, Norstrom K, Li X, Hornbuckle KC, Lehmler H-J: Simultaneous extraction and clean-up of PCBs and their metabolites from small tissue samples using pressurized liquid extraction. $J$ Chromatogr A 2008, 1214:37-46

26. Abraham VM, Lynn BC Jr: Determination of hydroxylated polychlorinated biphenyls by ion trap gas chromatography-tandem mass spectrometry. J Chromatogr A 1997, 790:131-141.

27. Sandanger TM, Dumas P, Berger U, Burkow IC: Analysis of HO-PCBs and $\mathrm{PCP}$ in blood plasma from individuals with high $\mathrm{PCB}$ exposure living on the Chukotka Peninsula in the Russian Arctic. J Environ Monit 2004, 6:758-765.

28. Sandau CD, Ayotte P, Dewailly E, Duffe J, Norstrom RJ: Analysis of hydroxylated metabolites of PCBs (OH-PCBs) and other chlorinated phenolic compounds in whole blood from Canadian Inuit. Environ Health Perspect 2000, 108:611-616.

29. Letcher RJ, Li HX, Chu SG: Determination of hydroxylated polychlorinated biphenyls (HO-PCBs) in blood plasma by high-performance liquid chromatography-electrospray ionization-tandem quadrupole mass spectrometry. J Anal Toxicol 2005, 29:209-216.

30. Kania-Korwel I, Barnhart CD, Stamou M, Truong KM, El-Komy MHME, Lein PJ, Veng-Pedersen P, Lehmler H-J: 2,2',3,5',6-Pentachlorobiphenyl (PCB 95) and its hydroxylated metabolites are enantiomerically enriched in female mice. Environ Sci Technol 2012, 46:11393-11401.

31. Kania-Korwel I, Duffel MW, Lehmler H-J: Gas chromatographic analysis with chiral cyclodextrin phases reveals the enantioselective formation of hydroxylated polychlorinated biphenyls by rat liver microsomes. Environ Sci Technol 2011, 45:9590-9596.

32. Wu X, Pramanik A, Duffel MW, Hrycay EG, Bandiera SM, Lehmler H-J, Kania-Korwel I: 2,2',3,3',6,6'-Hexachlorobiphenyl (PCB136) Is enantioselectively oxidized to hydroxylated metabolites by rat liver microsomes. Chem Res Toxicol 2011, 24:2249-2257.

33. Pham-Tuan H, Larsson C, Hoffmann F, Bergman A, Fröba M, Hühnerfuss $H$ : Enantioselective semipreparative HPLC separation of PCB metabolites and their absolute structure elucidation using electronic and vibrational circular dichroism. Chirality 2005, 17:266-280.

34. Kunisue T, Tanabe S: Hydroxylated polychlorinated biphenyls (OH-PCBs) in the blood of mammals and birds from Japan: Lower chlorinated OH-PCBs and profiles. Chemosphere 2009, 74:950-961.

35. Lehmler HJ, Robertson LW: Synthesis of hydroxylated PCB metabolites with the Suzuki-coupling. Chemosphere 2001, 45:1119-1127.

36. Bauer $U$, Amaro AR, Robertson LW: A new strategy for the synthesis of polychlorinated biphenyl metabolites. Chem Res Toxicol 1995, 8:92-95.

37. Determination of LODs (limits of detection) and LOQs (limit of quantification). http://www.und.edu/dept/chromatography/Docs/ Determination\%20of\%20LODs.pdf.

doi:10.1186/1752-153X-7-183

Cite this article as: Zhai et al:: Atropisomeric determination of chiral hydroxylated metabolites of polychlorinated biphenyls using HPLC-MS Chemistry Central Journal 2013 7:183.

Publish with ChemistryCentral and every
scientist can read your work free of charge
"Open access provides opportunities to our
colleagues in other parts of the globe, by allowing
anyone to view the content free of charge."
W. Jeffery Hurst, The Hershey Company.
- available free of charge to the entire scientific community
- peer reviewed and published immediately upon acceptance
- cited in PubMed and archived on PubMed Central
- yours - you keep the copyright
Submit your manuscript here:
http://www.chemistrycentral.com/manuscript/

